\title{
Two Newly Identified Gymnosporangium Species, G. japonicum and G. cornutumn, in Korea
}

\author{
Hye Young Yun, Seung Kyu Lee ${ }^{1 *}$, Kyung Joon Lee and Kyung Hee Kim ${ }^{1}$ \\ Department of Forest Resources, College of Agriculture and Life Sciences, Seoul National University, Suwon 441-744, Korea \\ ${ }^{\prime}$ Korea Forest Research Institute, Seoul 130-712, Korea
}

(Received on August 21, 2003; Accepted on October 14, 2003)

Two Gymnosporangium species, G. japonicum and $G$. cornutum, causing cedar-apple rust, were newly identified in Korea, and a new aecial host for each fungus was found by artificial inoculation. Detailed descriptions of the species were made based on macroscopic features (symptoms and signs) and light and scanning electron microscopic observations of spores and peridial cells. $G$. japonicum from Juniperus chinensis var. horizontalis had Photinia villosa as its new aecial host. G. cornutum from J. rigida showed its aecial stage on Sorbus alnifolia.

Keywords : Cedar-apple rust, Gymnosporangium cornutum, Gymnosporangium japonicum, Photinia villosa, Sorbus alnifolia.

In the $20^{\text {th }}$ century, taxonomic studies on the genus Gymnosporangium have been mainly focused on host ranges and light microscopic characters of spores and peridial cells (Hiratsuka, 1936a-e; Hiratsuka and Hiratsuka, 1980; Hiratsuka et al., 1992; Kern, 1973; Parmelee, 1965, 1971; Peterson, 1982; Wang and Lin, 1985). Hence, a need for detailed description of the fungal structures using electron microscopy was recognized to update fungal taxonomy especially in the Uredinales (Hiratsuka, 1971; Hiratsuka and Kaneko, 1975; Katsuya et al., 1980; Sato and Sato, 1982; Lohsomboon et al., 1990). It was suggested that fine surface structures of aeciospores and peridial cells in the genus Gymnosporangium could be important diagnostic parameters in identifying its species (Lee and Kakishima, 1999a, b; Lee et al., 1999).

Gymnosporangium species are major pathogenic fungi causing cedar-apple rust in Juniperus and in pomaceous plants of the Rosaceae (Agrios, 1997). Gymnosporangium is mainly distributed in the northern hemisphere, having about 60 species with 15 Roestelia species as anamorphs (Kern, 1973). In China, 18 Gymnosporangium spp. and 8 Roestelia spp. have been recorded (Zhuang, 1994), while 9

\footnotetext{
*Corresponding author.

Phone) +82-2-961-2625, FAX) +82-2-961-2595

E-mail) leesk77@foa.go.kr
}

Gymnosporangium spp. have been identified in Japan (Hiratsuka et al., 1992). In Korea, five Gymnosporangium spp. including G. asiaticum, G. clavariiforme, G. miyabei, $G$. yamadae, and $G$. shirainum have been recorded (Hiratsuka, 1935, 1940; Takimoto, 1916; Park, 1958). However, collections for G. miyabei and G. shirainum have not been made since their first report.

During the survey of cedar apple-rust, we found two species of Gymnosporangium, G. cornutum and $G$. japonicum, unrecorded in Korea. This report presents the detailed descriptions of the species observed by light microscopy (LM) and scanning electron microscopy (SEM). Aecial host ranges of the rust fungi were also investigated based on specimen collections and by artificial inoculation.

\section{Materials and Methods}

Collection of specimens. A total of 28 telial and 18 aecial specimens of Gymnosporangium species were collected from various regions of Korea from 1984 to 2002, and deposited at the Herbarium of the Korea Forest Research Institute (HKFRI). Eight dry specimens were provided by the National Mycological Herbarium of Biosystematics Research Institute (DAOM) and the Mycological Herbarium, the Institute of Microbiology, Academia Sinica, China (HMAS). Fresh telial materials were collected from various regions in Korea during a recent survey from 1999 to 2001 , and used as inocula on aecial hosts, from which fresh aecial materials were also obtained for morphological examinations by LM and SEM.

Inoculation of teliospores on aecial hosts. Fresh telia were collected from Juniperus species during the spring season of 2001 in Seoul and its vicinities and stored in a refrigerator at about $4^{\circ} \mathrm{C}$ until use. Teliospore inoculum was made and inoculated on Rosaceous plants by the procedures of Pearson et al. (1977) and Aldwinkle et al. (1977).

Teliospores from telia in branches and trunks of Juniperus trees were suspended in sterile water, and sufficiently sprayed onto the leaves of Rosaceous plants such as Amelanchier asiatica (Siebold et Zucc.) Endlicher, Chaenomeles sinensis Koehne, C. lagenaria (Loiselur) Koidzumi, Crataegus pinnatifida Bunge, Eribotrya japonica (Thunb. ex Murray) Lindley, Pyrus pyrifolia var. culta Nakai, P. ussuriensis Maxim., Sorbus commixta Hedl., S. alnifolia (Siebold et Zucc.) K. Koch, Photinia glabra (Thunb. ex Murray) 
Maxim., P. villosa (Thunb. ex Murray) DC., Malus sieboldii (Regel) Rehder, and $M$. pumila Mill. These species have been recorded as aecial host plants of Gymnosporangium (Kern, 1973; Lee, 1999). Two- to three-year-old Rosaceous plants, three per each species, were used in this study. The plants were placed in two humidified chambers at room temperature for 2-3 days.

Light microscopy (LM). Light microscopic characters of specimens examined under a compound light microscope (Axiophot, Zeiss, Germany) included shape and size of peridium and peridial cells; shape, size, and color of aeciospores; and thickness of cell walls of aeciospores and teliospores. Aecial specimens obtained from artificial inoculation on Rosaceous plants were also compared with those of natural collections.

Scanning electron microscopy (SEM). Fine surface structures of aeciospores and peridial cells were examined by SEM. Aeciospores and peridial cells obtained from natural host and infected plants by artificial inoculation were dusted on doublesided adhesive tapes on specimen holders and then coated with gold using a Hitachi E-1010 Ion Sputter, and then examined under an S-3000N SEM (Hitachi, Japan) at $15 \mathrm{kV}$. Types of the aeciospore surface structures and peridial cell structures were identified according to Lee and Kakishima (1999a, b).

Identification and description of species. Identification and description of the cedar-apple rust fungi were based on the data from previous studies (Kern, 1973; Hiratsuka et al., 1992; Lee and Kakishima, 1999a, b), while scientific names of host plants were based on Lee (1999), Chang (1994), and Krussmann (1985).

\section{Results and Discussion}

Gymnosporangium cornutum Arth. ex Kern. Telia caulicolous formed irregular fusiform swellings of the smaller branches (Fig. 1A), applanate and low, or pulvinate, and dark-brown. Teliospores were two-celled, rarely threecelled, globoid, 16-29×36-63 $\mu \mathrm{m}$ (Fig. 1B), regular, thinwalled, 1.4-2.8 $\mu \mathrm{m}$, with one to two pores near the septum or one apical in the upper cell, and covered ellipsoid with hyaline papillae. Spermogoia and aecia foliicolous (Fig. 1C, D) were also possibly fructicolous, while aecia roestelioid caused some hypertrophy. Peridia were cornuted, rupturing at apex, becoming rather lacerate but retaining tubular form, 0.5-2.5 mm high, while peridial cells were rounded rhomboidal, 48-101 $\mu \mathrm{m}$ long, outer cell smooth (type S), side cells moderately rugose (type MR), and inner cells small papillate (Type SP) (Fig. 1E). Aeciospores were globoid, 17-27×18-28 $\mu \mathrm{m}$, walls yellow-brown, 1.3-2.5 $\mu \mathrm{m}$ thick, and minutely coronate (Type MC) (Fig. 1F).

Specimens examined: O, I on Sorbus alnifolia (Siebold et Zucc.) K. Koch, Gwanak-gu, Seoul, 8 July 2000, H. Y. Yun (HKFRI 2071); Boeun-gun, Chungbuk, 15 July 1999, S. K. Lee (HKFRI 931); Nowon-gu, Seoul, 20 June 1998, S. K. Lee (HKFRI 928, 935); 20 June 2000, H. Y. Yun [HKFRI 2053, a result of teliospore inoculation of G. cornutum

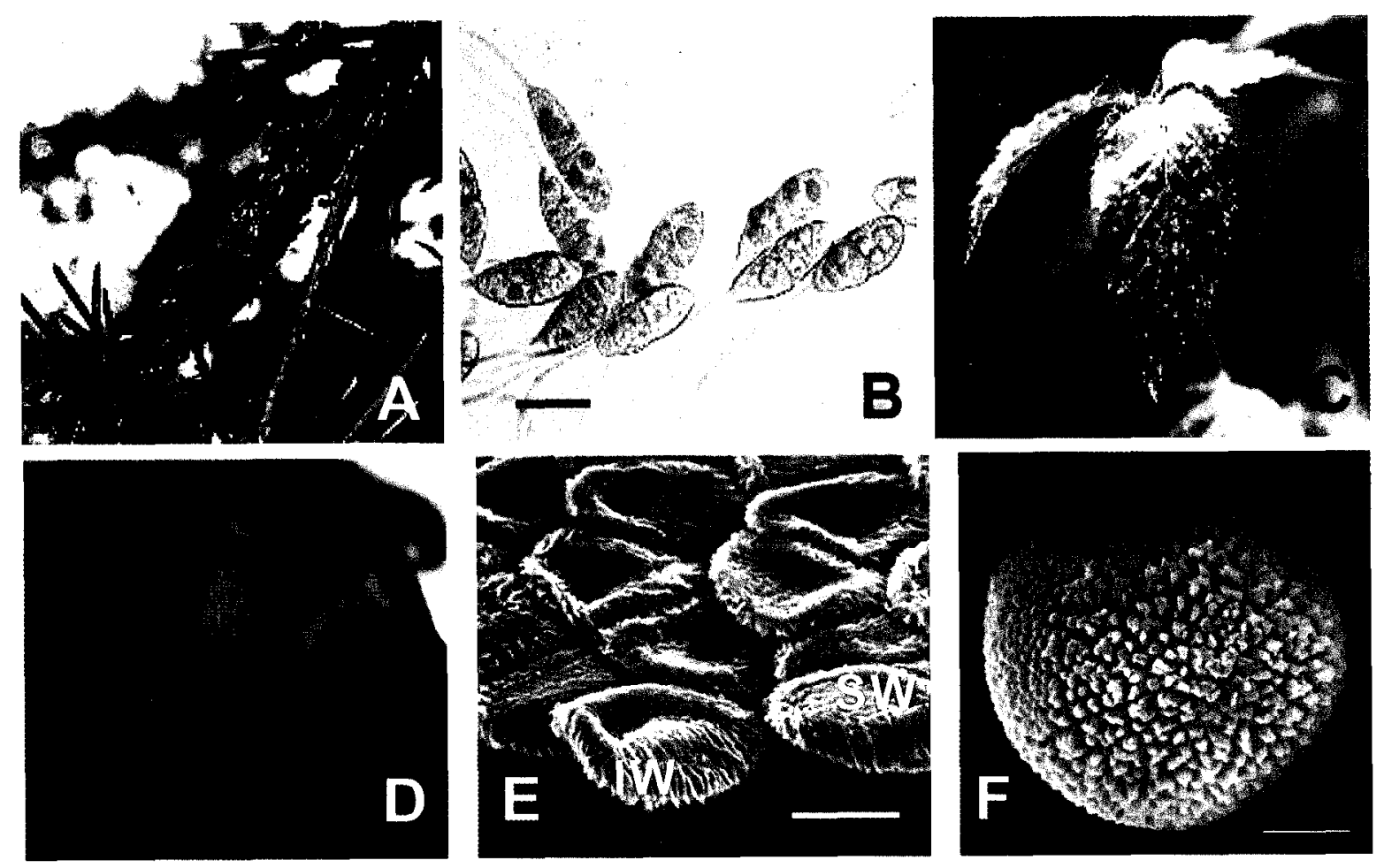

Fig. 1. Macroscopic and microscopic features of Gymnosporangium cornutum. A: Telia on J. rigida. B: Teliospores $(\times 400)$ (scale bar: 20 $\mu \mathrm{m})$ C: Artificially-induced spermogonia on S. alnifolia. D: Artificially-induced aecia on S. alnifolia. E: Surface structures of peridial cells (IW: inner wall, SW: side wall). F: Surface structure of an aeciospore. (scale bars: $E=15 \mu \mathrm{m}, F=5 \mu \mathrm{m}$ ) 
Table 1. Result of artificial inoculation of teliospores of two Gymnosporangium species on 13 Pomaceous plants ${ }^{\mathrm{a}}$

\begin{tabular}{lcc}
\hline \hline \multirow{2}{*}{ Aecial host plant } & \multicolumn{2}{c}{ Rust fungal species } \\
\cline { 2 - 3 } & G. japonicum & G. cornutum \\
\hline Amelanchier asiatica & $-{ }^{\mathrm{b}}$ & - \\
Chaenomeles sinensis & - & - \\
Chaenomeles lagenaria & - & - \\
Crataegus pinnatifida & - & - \\
Eribotrya japonica & - & - \\
Malus sileboldii & - & - \\
Malus pumila & - & - \\
Photinia glabra & - & - \\
Photinia villosa & + & - \\
Pyrus pyrifolia var. culta & - & - \\
Pyrus ussuriensis & - & - \\
Sorbus alnifolia & - & + \\
Sorbus commixta & - & - \\
\hline
\end{tabular}

"These woody Rosaceae species are known as aecial hosts of Gymnosporangium spp. in Korea.

b+ means "successively forming spermogonia and ascia" and - "not forming spermogonia and ascia".
(HKFRI 2018)]; O, I on Sorbus aucuparia L., 4 September 1977 (DAOM 166487); O, I on Sorbus decora, September 1951 (DAOM 920471); III on Juniperus rigida Sieb. et Zucc., Gwacheon, Gyeonggi, 10 April 2001, H. Y. Yun (HKFRI 2018); 6 April 2000, S. K. Lee (HKFRI 1794); 15 April 2000, S. K. Lee (HKFRI 1792); 22 April 2000, S. K. Lee, (HKFRI 1793); 22 April 2000, S. K. Lee (HKFRI 1788); 3 May 2001, H. Y. Yun (HKFRI 1985); 28 March 2002, H. Y. Yun (HKFRI 1984); Gwanak-gu, Seoul, 5 May 2000, S. K. Lee (HKFRI 517), K. H. Kim (HKFRI 518, 519, 520); 20 June 1961 (HMAS 44512).

Hosts in Korea: O, I on Sorbus alnifolia (Sieb. et Zucc.) K. Koch. III on Juniperus rigida Sieb. et Zucc.

Geographical distribution: G. cornutum was not common in Korea and could be collected only from two locations, Seoul and Boeun.

Remarks: As shown in Table 1, the artificial inoculation of teliospores collected from $J$. rigida resulted in the successful production of spermogonia and aecia only on leaves of $S$. alnifolia among 13 tested aecial host trees. Although other Sorbus spp. are also aecial hosts of $G$. corunutum, they are not grown in Korea. Therefore, host alternation of Gymnosporangium species between J. rigida,

Table 2. Morphological characteristics of teliospores, aeciospores, and peridial cells of Gymnosporangium cornutum

\begin{tabular}{|c|c|c|c|c|}
\hline Structure & Present study & $\begin{array}{l}\text { Hiratsuka et al. } \\
\text { (1992) }\end{array}$ & Kern (1973) & $\begin{array}{l}\text { Lee and } \\
\text { Kakishima (1999) }\end{array}$ \\
\hline Telium & $\begin{array}{l}\text { Caulicolous, on smaller } \\
\text { branches }\end{array}$ & $\begin{array}{l}\text { Chiefly caulicolous, } \\
\text { foliicolous }\end{array}$ & $\begin{array}{l}\text { Chiefly caulicolous, } \\
\text { foliicolous } \\
\text { on smaller branches, }\end{array}$ & $-^{c}$ \\
\hline \multicolumn{5}{|l|}{ Teliospore } \\
\hline Cell number & 2 , rarely 3 & 2 & 2 & - \\
\hline Shape & Globoid & Ellipsoid & Ellipsoid & - \\
\hline Size $(\mu \mathrm{m})$ & $16-29 \times 36-63$ & $12.5-30 \times 25-55$ & $15-24 \times 30-58$ & - \\
\hline Wall thickness $(\mu \mathrm{m})$ & $1.4-2.8$ & $1.0-2.5$ & $1.0-2.0$ & - \\
\hline No. of pores & $\begin{array}{l}1-2 \text { near septum } \\
\text { or } 1 \text { apical in upper cell }\end{array}$ & $\begin{array}{l}1-2 \text { near septum } \\
\text { or } I \text { apical in upper cell }\end{array}$ & $\begin{array}{l}1-2 \text { near septum } \\
\text { or } 1 \text { apical in upper cell }\end{array}$ & - \\
\hline \multicolumn{5}{|l|}{ Aeciospore } \\
\hline Type of surface Structure & $\mathrm{MC}^{\mathrm{a}}$ & - & - & $\mathrm{MC}$ \\
\hline Wall thickness $(\mu \mathrm{m})$ & $1.3-2.5$ & $2.0-2.5$ & $1.8-3.0$ & $2.0-2.5$ \\
\hline Size $(\mu \mathrm{m})$ & $17-27 \times 18-28$ & $18-27 \times 21-31$ & $16-25 \times 21-29$ & $16-25 \times 21-29$ \\
\hline \multicolumn{5}{|l|}{ Peridial cells } \\
\hline \multicolumn{5}{|l|}{ Type of surface Structure ${ }^{b}$} \\
\hline OW & $\mathrm{S}$ & - & - & $S$ \\
\hline SW & MR & - & - & MR \\
\hline IW & SP & - & - & $\mathrm{SP}$ \\
\hline Length $(\mu \mathrm{m})$ & $48-101$ & $40-110$ & $60-110$ & - \\
\hline
\end{tabular}

${ }^{\mathrm{a}} \mathrm{MC}$ : type MC (minutely coronate; Lee and Kakishima, 1999a).

${ }^{\circ}$ OW: outer wall; SW: side wall; IW: inner wall; MR: type MR (Moderately rugose); S: type S (smooth); SP: type SP (small papillae; Lee and Kakishima, 1999b).

${ }^{\mathrm{c}}$ Not described. 

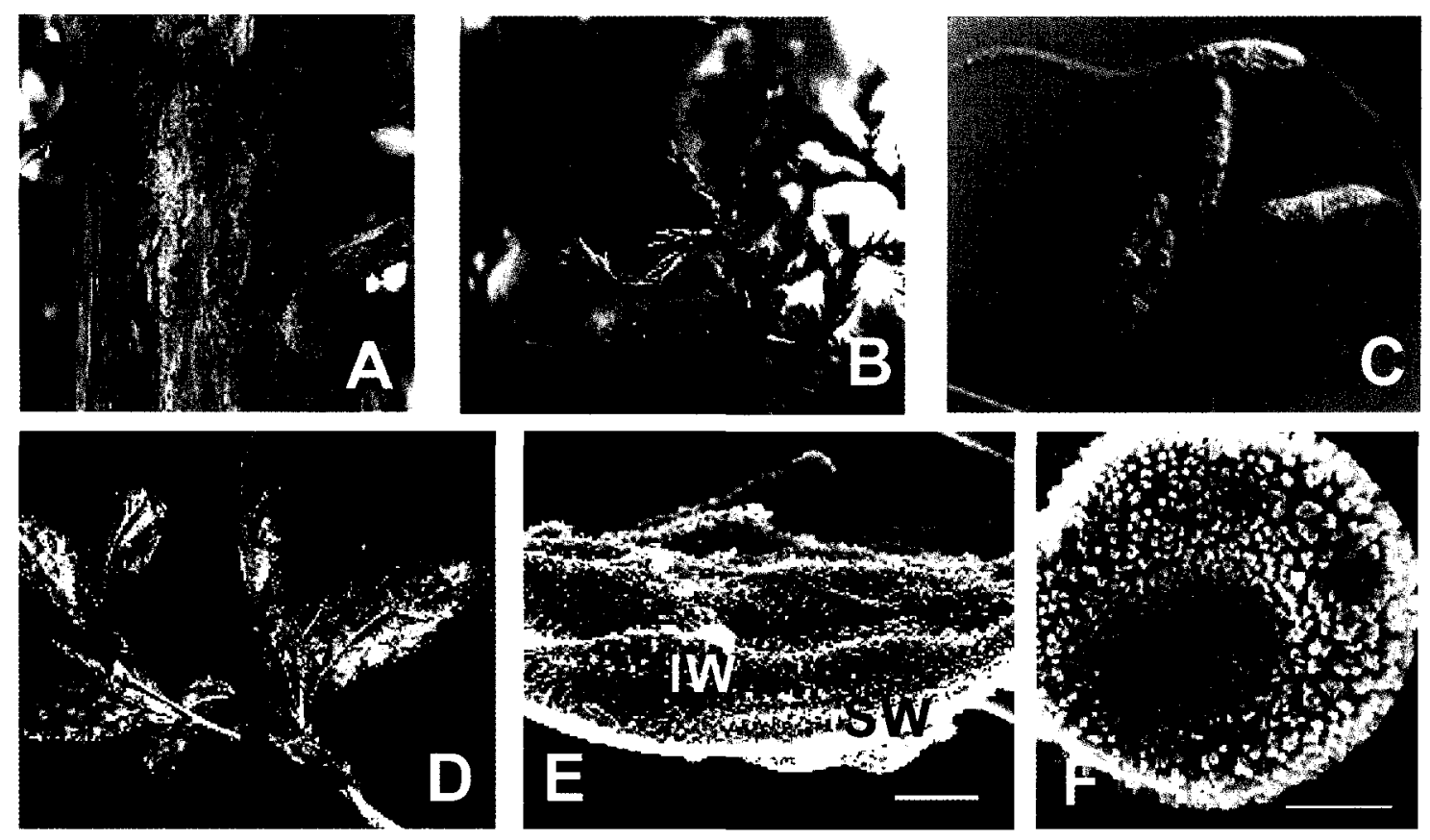

Fig. 2. Macroscopic and microscopic features of Gymnosporangium japonicum. A: Telia on $J$. chinensis (on trunk). B: Telia on $J$. chinensis var. horizontalis (on branch). C: Teliospores $(\times 400)($ Scale bar: $30 \mu \mathrm{m})$ D: Artificially-induced spermogonia on $P$. villosa. E: Surface structures of peridial cells (TW: inner wall, SW: side wall). F: Surface structure of an aeciospore. (scale bars: $\mathbf{E}=10 \mu \mathrm{m}, \mathbf{F}=$ $5 \mu \mathrm{m})$.

a telial host, and $S$. alnifolia, a pomaceous aecial host, was verified for the first time in Korea. No significant differences were noted between the present and the previous descriptions (Table 2). However, size of peridial cells of this rust fungus was relatively smaller as compared to those of $G$. cornutum reported in other countries (Kern, 1973; Hiratsuka et al., 1992). Fine surface structure of the aeciospores was minutely coronate type (Type MC). Fine surface structures of peridial cells were smooth (type $S$ ) on outer walls, moderately rugose (type $\mathrm{MR}$ ) on side walls, and small papillate (SP) on inner walls (Figure 1, Table 2).

Gymnosporangium japonicum P. Sydow. Telia caulicolous on twigs, branches and trunks, were irregularly wedgeshaped, 3-6 mm high, and orange-brown (Fig. 2A, B). Teliospores were two-celled or rarely three-celled, ellipsoid and long-ellipsoid, 13-22×36-70 $\mu \mathrm{m}$, walls pale orangebrown, 1.0-2.7 $\mu \mathrm{m}$ thick, usually with one or two pores near septum (Fig. 2C). Spermagonia and aecia were foliicolous and caulicolous (Fig. 2D); aecia hypophyllous, roestelioid, 2-5 mm high; peridia dehiscent at apex, retaining somewhat tubular shape; peridial cells linear rhomboid, 62-117 $\mu \mathrm{m}$ long, outer walls smooth (type $S$ ), inner and side walls sparsely echinulate (type SE) (Fig. 2E); and aeciospores globoid, 16-21×20-26 $\mu \mathrm{m}$, walls dark yellow, 1.1-2.8 $\mu \mathrm{m}$ thick, small coronate (type SC) (Fig. 2F).

Specimens examined: O. I on Photinia villosa (Thunb. ex
Murray) DC., Jeju-si, Jeju-do, 13 July 1999, S. K. Lee (HKFRI 694); Jeju-si, Jeju-do, 29 July 1999, S. K. Lee (HKFRI 695); Jeju-si, Jeju-do, 29 August 2001, H. Y. Yun (HKFRI 142, 144, 145, 147); Jeju-si, Jeju-do, 29 August 2001, H. Y. Yun (HKFRI 148), 23 August 2001 (HKFRI 2054), 20 June 2001, H. Y. Yun (HKFRI 2055, a result of teliospore inoculation of $G$. japonicum (HKFRI 2019)); 20 June 2001, H. Y. Yun [HKFRI 2056, result of teliospore inoculation of $G$. japonicum (HKFRI 2020)]. O. I on Photinia laevis var. villosa, 22 June 1934 (SAC 14); 21 June 1934 (SAC 5). O. I on Photinia parvifolea, 26 June 1932 (HMAS 11147). III on Juniperus chinensis L., Kangneung, Kangwon, 9 April 1988, S. K. Lee (HKFRI 504); Jeju-si, Jeju-do, 9 April 2002, S. K. Lee (HKFRI 1987); 19 April 2001, S. K. Lee (HKFRI 2021); Dongdaemun-gu, Seoul, 19 April 2002, H. Y. Yun (HKFRI 1988); Dongdaemun-gu, Seoul, 16 April 2000, S. K. Lee (HKFRI 1784); Suwon, Gyeonggi, 31 March 2002, H. Y. Yun (HKFRI 1989); 13 April 2001, H. Y. Yun (HKFRI 1992); Suwon, Gyeonggi, 20 April 2001, H. Y. Yun (HKFRI 2019). III on Juniperus chinensis L. var. sargentii Henry, Jeju-si, Jeju-do, 19 April 2001, S. K. Lee (HKFRI 2019); 9 April 2002, H. Y. Yun (HKFRI 1990, 1994), 19 April 2002, S. K. Lee (HKFRI 1996); Gyeongju, Gyeongbuk, 12 April 2002, K. H. Kim (HKFRI 1991). III on Juniperus chinensis L. var. globosa Hornibr, Jeju-si, Jeju-do, 9 April 2002, S. K. Lee (HKFRI 1997). III on Juniperus chinensis 
Table 3. Morphological characteristics of teliospores, aeciospores, and peridial cells of Gymnosporangium japonicum

\begin{tabular}{|c|c|c|c|c|}
\hline Structure & Present study & $\begin{array}{l}\text { Hiratsuka et al. } \\
\text { (1992) }\end{array}$ & Kern (1973) & $\begin{array}{l}\text { Lee and } \\
\text { Kakishima (1999) }\end{array}$ \\
\hline Telium & $\begin{array}{l}\text { Caulicolous, on twigs, } \\
\text { branches and trunks }\end{array}$ & $\begin{array}{l}\text { Caulicolous, on twigs } \\
\text { or branches }\end{array}$ & $\begin{array}{l}\text { Caulicolous, on twigs } \\
\text { or branches }\end{array}$ & $-{ }^{c}$ \\
\hline \multicolumn{5}{|l|}{ Teliospore } \\
\hline Cell number & 2 & 2 & 2 & - \\
\hline Shape & Ellipsoid & Ellipsoid & Ellipsoid & - \\
\hline $\operatorname{Size}(\mu \mathrm{m})$ & $13-22 \times 36-70$ & $18-24 \times 46.5-70$ & $17-25 \times 57-66$ & - \\
\hline Wall thickness $(\mu \mathrm{m})$ & $1.0-2.7$ & $1.8-2.5$ & $1.0-1.5$ & - \\
\hline No. of pores & 1 or 2 near the septum & 2 near the septum & 2 septate & - \\
\hline \multicolumn{5}{|l|}{ Aeciospore } \\
\hline Type of surface Structure & $\mathrm{SC}^{\mathrm{a}}$ & - & - & $\mathrm{SC}$ \\
\hline Wall thickness $(\mu \mathrm{m})$ & $1.1-2.8$ & $1.0-1.8$ & $2.5-3.5$ & $2.5-3.5$ \\
\hline Size $(\mu \mathrm{m})$ & $16-21 \times 20-26$ & $15-22 \times 18-28$ & $17-19 \times 19-23$ & $17-19 \times 19-23$ \\
\hline \multicolumn{5}{|l|}{ Peridial cells } \\
\hline \multicolumn{5}{|l|}{ Type of surface Structure ${ }^{b}$} \\
\hline OW & $\mathbf{S}$ & - & - & $\mathbf{S}$ \\
\hline SW & SE & - & - & SE \\
\hline IW & SE & - & - & SE \\
\hline Length $(\mu \mathrm{m})$ & $62-117$ & $57-120$ & $60-120$ & - \\
\hline
\end{tabular}

${ }^{a}$ SC: type SC (small coronate; Lee and Kakishima, 1999a).

'OW: outer wall; SW: side wall; IW: inner wall; S: type S (smooth); SE: type SE (sparsely echinulate; Lee and Kakishima, 1999b).

${ }^{c}$ Not described.

L. var. horizontalis Nakai, Suwon, Gyeonggi, 20 April 2001, H. Y. Yun (HKFRI 2020); Jeju-si, Jeju-do, 9 April 2001, S. K. Lee (HKFRI 1993), 19 April 2002, S. K. Lee (HKFRI 1995).

Hosts in Korea: O, I on Photinia villosa (Thunb. ex Murray) DC., Photinia villosa var. brunnea Nakai. III on Juniperus chinensis L., Juniperus chinensis L. var. horizontalis Nakai, Juniperus chinensis L. var. sargentii A. Henry, Juniperus chinensis L. var. globosa Hornibr.

Geographical distribution: This cedar-apple rust fungus was mainly collected from the northern parts of South Korea including Kyeonggi province, Kangwon province, and Kyeongbuk province.

Remarks: $G$. japonicum is a newly reported cedar-apple rust fungus in Korea. No significant differences in the mycological characters of $G$. japonicum were noted between the present and the previous descriptions (Table 3). Hiratsuka et al. (1992) and Kern (1973) described that telia are caulicolous and growing on twigs and branches, but telia that formed on the trunks were identified in the present study. Aecia of $G$. japonicum are known to be produced only on leaves of aecial hosts (Hiratsuka et al., 1992; Kern, 1973). However, results of this study showed that aecia are also produced on twigs of Photinia villosa, which could become a new character for identifying this species. As shown in Fig. 2, ultrastructural examination under the SEM revealed that surface structures of inner and side walls of peridial cells were sparsely echinulate (type SE), which is unique to this species, compared with the other species as reported by Lee and Kakishima (1999b).

From the artificial inoculation with this fungus, a positive result was obtained only on $P$. villosa among 13 tested aecial hosts as reported in other countries (Table 1) (Kern, 1973; Hiratsuka et al., 1992), and mature aecia were obtained 70 days after inoculation. Leaves of $P$. villosa were infected by telia from $J$. chinensis in Suwon and from $J$. chinensis var. horizontalis in Jeju-do, and produced spermogonia and aecia. Other plant species showed no sign of spermogonia and aecia on their leaves.

In Korea, cedar-apple rust caused by $G$. japonicum has been known to rarely occur because the aecial host, $P$. villosa, naturally grows in mountainous areas in Korea, while the telial host, $J$. chinensis, is generally limited to urban areas as a landscape tree.

Specimens used in this study have been deposited at the Mycological Herbarium, The Korea Forest Research Institute, Seoul.

\section{Acknowledgment}

The authors wish to thank Dr. Young Ho Kim of the School of Agricultural Biotechnology, College of Agriculture and Life Sciences, Seoul National University for the valuable suggestions and editorial comments. 


\section{References}

Agrios, G. N. 1997. Plant Pathology. Academic Press 4th ed. New York, pp. 368-381.

Aldwinckle, H. S., Lamb, R. C. and Gustafson, H. L. 1977. Nature and inheritance of resistance to Gymnosporangium juniperi-virginianae in apple cultivar. Phytopathology 67:259266.

Chang, J. S. 1994. A reconsideration of nomenclatural problems on Korean plants and the Korean woody plant list. Kor. $J$. Plant Tax. 24:95-124.

Hiratsuka, N. 1935. Uredinales collected in Korea I. Bot. Mag. Tokyo 49:145-152.

Hiratsuka, N. 1936a. Gymnosporangium of Japan I. Bot. Mag. Tokyo 50:481-488.

Hiratsuka, N. 1936b. Gymnosporangium of Japan II. Bot. Mag. Tokyo 50:549-585.

Hiratsuka, N. 1936c. Gymnosporangium of Japan III. Bot. Mag. Tokyo 50:593-599.

Hiratsuka, N. 1936d. Gymnosporangium of Japan IV. Bot. Mag. Tokyo 50:661-668.

Hiratsuka, N. 1936e. Gymnosporangium of Japan V. Bot. Mag. Tokyo 51:1-8.

Hiratsuka, N. 1936f. Inoculation experiments with heteroecious species of the Japanese rust fungi.. Bot. Mag. Tokyo 592:213217.

Hiratsuka, N. 1940. Uredinales collected in Korea. Bot. Mag. Tokyo 54:427-432.

Hiratsuka, Y. 1971. Spore surface morphology of pine stem rusts of Canada as observed under a scanning electron microscope. Can. J. Bot. 49:371-294.

Hiratsuka, N. and Kaneko, S. 1975. Surface structure of Coleosporium spore. Rept. Tottori Mycol. Inst. (Japan) 12:113.

Hiratsuka, Y. and Hiratsuka, N. 1980. Morphology of spermogonia and taxonomy of rust fungi. Rept. Tottori Mycol. Inst. 18:257-268.

Hiratsuka. N., Sato, S., Katsuya, K., Kakishima, M., Hirastuka, Y., Kaneko, S., Ono, Y., Sato, T., Harada, Y., Hiratsuka, T. and Nakayama, K. 1992. The Rust Flora of Japan. Tsukuba Shuppankai, Tsukuba, pp. 457-476.

Katsuya, K., Kakishima, M. and Sato, S. 1980. Spore surface structures of three Pileolaria species in Japan. Rept. Tottori
Mycol. Inst. (Japan) 18:163-167.

Kern, F. D. 1973. A Revised Taxonomic Account of Gymnosporangium. Pennsylvania State University Press, University Park, Pennsylvania.

Krussmann, G. 1985. Manual of Cultivated Conifers. pp. 15-153.

Lee, S. K. and Kakishima, M. 1999a. Aeciospore surface structures of Gymnosporangium and Roestelia (Uredinales). Mycoscience 40:109-120.

Lee, S. K. and Kakishima, M. 1999b. Surface structures of peridial cells of Gymnosporangium and Roestelia (Uredinales), Mycoscience 40:121-131.

Lee, S. K., Kakishima, M. and Zhuang J. Y. 1999. A new rust species of Roesteila on Sorbus collected in China, Mycoscience 40:437-440.

Lee, T. B. 1999. Illustrated flora of Korea. Hyang-mun Pub. Co. Seoul (in Korean).

Littlefield, L. J. and Heath, M. C. 1979. Ultrastructure of rust fungi, Academic Press, New York, pp. 20-45.

Lohsomboon, P., Kakishima, M. and Ono, Y. 1990. Aeciospore surface structure of the Uredinales. Trans. Mycol. Soc. Japan. 23:51-63.

Park, C. S. 1958. Fungus Disease of Plants in Korea. Pept. 1. Coll. of Agric. Chungnam National University. Daejon, Korea. $106 \mathrm{p}$.

Parmelee, J. A. 1965. The genus Gymnosporangium in eastern Canada. Can. J. Bot. 43:239-267.

Parmelee, J. A. 1971. The genus Gymnosporangium in western Canada. Can. J. Bot. 49:903-926.

Pearson, R. C., Aldwinckle, H. S. and Seem, R. C. 1977. Teliospore germination and basidiospore formation in Gymnosporangium juniperi-virginianae: A regression model of temperature and time effects. Can. J. Bot. 55:2832-2837.

Peterson, R. S. 1982. Rust fungi (Uredinales) on Cupressaceae. Mycologia 74:903-910.

Sato, T. and Sato, S. 1982. Aeciospore surface structure of the Uredinales. Trans. Mycol. Soc. Japan 23:51-63.

Takimoto, S. 1916. Note worthy disease of plants in Korea. Bull. Japan. Plant Dis. Insect. 3:28-30.

Wang, Y. C. and Lin, G. 1985. Taxonomic studies on Gymnosporangium in China. Acta Mycol. Sinica 4:24-34.

Zhuang, J. Y. 1994. A review of floristic investigations of rust fungi in China. Trans. Mycol. Soc. China 9:81-94. 